\title{
NEW PLANT TAXA FROM COLORADO, NEW MEXICO, AND ARIZONA
}

\author{
N. Duane Atwood ${ }^{1}$ and Stanley L. Welsh ${ }^{1,2}$
}

\begin{abstract}
Aвstract.-Descriptions of previously undescribed taxa are provided for plant taxa from Colorado (Phacelia), New Mexico (Phacelia; Mentzelia), and Arizona (Xylorhiza).

Resumen.-Se proveen descripciones de taxa de plantas de Colorado (Phacelia), Nuevo Mexico (Phacelia; Mentzelia), y Arizona (Xylorhiza) que no se habían descrito con anterioridad.
\end{abstract}

During several years of work in the field by Dr. N. Duane Atwood, several plant taxa were discovered that require description and naming. Hence the following plants are herein named and described. They represent significant additions to the floras of Colorado, New Mexico, and Arizona.

\section{PhaCelia}

\section{Phacelia gina-glenneae N.D. Atwood \& S.L. Welsh, sp. nov.}

TyPe.-USA, Colorado, Grand County, Zone $12,4438667 \mathrm{~N}, 391135 \mathrm{E}$, on very white, tan shale soils, N.D. Atwood and Gina Glenn 33623. Holotype: BRY. Isotypes: B, BRY, CAS, CSU, GH, JEPS, MO, NMC, NY, POM, RM, RSA, UNM, US.

Diagnosis.-Similis Phacelia formosula Osterhout sed in caulibus brevioribus plerumque solitariis ramosis minoribus, annuis definite (nee biennis), floibus minoribus, et foliis e lobis latioribus et pubesentibus sparsis differt.

DESCRIPTION.-Annual from a slender taproot, 5.5-12 (10) cm high by $2-10$ (1.6) $\mathrm{cm}$ wide; stems solitary or with 2-6 lateral branches from the base to below the terminal set of cymes; copiously glandular, papillose to whitish hispidcanescent; leaves irregularly lobed to pinnatifid, longer than broad and thickened, light green; cauline and basal leaves petiolate; main stem and lateral branches terminating in 2-3 helicoid cymes; flowers on short stout pedicels mostly less than $2 \mathrm{~mm}$ long; calyx narrowly linear spathulate to more broadly so on one lobe, $4.2-5.5 \mathrm{~mm}$ long by $0.9-1.8 \mathrm{~mm}$ wide, stipitate- glandular and scabrous; corolla broadly campanulate, $4.5 \mathrm{~mm}$ long by $7 \mathrm{~mm}$ broad, the tube 1.5-2 mm long, white-yellow, the veins prominent, the lobes broad and minutely pubescent; stamens and style to $1.3 \mathrm{~cm}$ long, the style bifid except for the lower $6 \mathrm{~mm}$, pubescent; immature seeds reddish brown, pitted, $2.6-3.3 \mathrm{~mm}$ long, $0.8-1.3 \mathrm{~mm}$ wide, narrowly excavated on each side of the central elevated ridge, the ends upturned and pointed at the tips and rounded basally, the margins thickish and entire, sharper edged on one side more than the other.

REMARKS.-This species from Colorado was discovered by Gina Glenn, botanist for the U.S. Fish and Wildlife Service in Grand Junction, Colorado. It was brought to my attention while I (N.D. Atwood) was working on Phacelia formosula Osterhout (1919. Bulletin of the Torrey Botanical Club 46:54) with U.S. Fish and Wildlife Service botanists in 2009. Upon completion of our work on the Osterhout phacelia, we traveled to look at the population of phacelia Gina had located earlier in Grand County. Upon arrival at the site and after a quick look at plants in the population, it was obvious that the plants belonged to the crenulatae group of phacelias on which I had completed my dissertation (Atwood 1975), and that they did not match any in that group. We selected as specimens several growth stages of the plants sufficient for the types, and in addition to recording location and habitat data, we prepared labels for the type collection and duplicates.

This distinctive taxon is known only from the type locality on very white tan-colored

\footnotetext{
${ }^{1}$ Stanley L. Welsh Herbarium, Monte L. Bean Life Science Museum, Brigham Young University, Provo, UT 84602

2E-mail: slslwelsh@aol.com
} 
shale/clay substrates. It was associated with Astragalus kentrophyta, Chrysothamnus, Artemisia tridentata, and Purshia tridentata. The soil at the time of collection was still wet an inch under the surface and was covered with rocks and flat building stone. These flat stones are sought after by builders, and their removal might be a significant threat to this species. Additional surveys should be completed to determine if other populations exist in this vicinity and elsewhere where similar building stones occur on shale substrates.

Phacelia gina-glenneae is most closely related to populations bearing the name $P$. formosula var. schulyii, which are from northern Colorado in the Laramie River Valley, westsouthwest of Honholtz Lake. Phacelia ginaglenneae differs from the Schully populations of $P$. formosula in the shorter, less branched, mostly solitary stem, $5.5 \mathrm{~cm}$ by $12(16) \mathrm{cm}$ tall by $2-10(16) \mathrm{cm}$ wide, strictly an annual versus a biennial (rarely annual in $P$. formosula), small flowers (4.2-4.5 mm long, 0.9-1.8 mm wide vs. $6 \mathrm{~mm}$ wide and $6 \mathrm{~mm}$ long in P. formosula), leaves more broadly lobed and less pubescent.

\section{Phacelia cliffordii N.D. Atwood \&} S.L. Welsh, sp. nov.

TyPe.-USA, New Mexico, Navajo County, Navajo Indian Reservation, 3.5 miles northwest of Dilkon, $35^{\circ} 25.421^{\prime} \mathrm{N}, 40^{\circ} 21.712^{\prime} \mathrm{W}$, at $6214 \mathrm{ft}$. elevation, on steep rocky, south-facing slope; ash deposit member covered by basalt of Bidahochie Formation, N.D. Atwood, A. Clifford, and J.V. Atwood 33512. Holotype: BRY! Isotypes: B, BRY, CAS, CSU, GH, JEPS, MO, Navajo Nation, NMC, NY, POM, RM, RSA, UNM, US.

DiagnOSIS.-Similis Phacelia crenulata var. corrugate sed in seminibus minoribus atrocacao bruneis, floribusminoribus albis, caulibus rubescentibus dense glandularibus, pubescentiis hirtellis vel hirsutis et hispidis sparsis differt.

Description.-Plants annual, with 1-5 stems from the base, $11.5-23 \mathrm{~cm}$ tall, $0.6-27$ $\mathrm{cm}$ wide, densely covered throughout with short-stipitate, glandular hairs, short simple hairs to setose hispid pubescence; leaves petiolate, the blades simple to pinnately lobed, $0.5-2.3 \mathrm{~cm}$ long, $0.5-1.5 \mathrm{~cm}$ wide, the petiole 0.5-8 mm long; inflorescence in 1-3 terminal scorpioid helicoid cymes to $10 \mathrm{~cm}$ long and 5to 30-flowered; flowers white, small, 3-4.2 mm long, $2 \mathrm{~mm}$ wide, short-campanulate; sepals linear, $2.5 \mathrm{~mm}$ long in flower, $3.5-3.7 \mathrm{~mm}$ long in fruit, recurved at the tip; mature seeds cymbiform, dark chocolate colored, $3.3 \mathrm{~mm}$ long, $1.8 \mathrm{~mm}$ wide, corrugated on the inside of the margins and on one side of the ridge, finely pitted on the ventral side and cross-corrugated on the dorsal side, except for the smooth margins.

REMARKS.-This plant is known only from the type locality where it was discovered by Arnold Clifford. It is evidently endemic to the Bidahochie Formation, which is rarely exposed and mostly covered by the thicker more common basalt of that formation.

I (N.D. Atwood) have examined a large set of plants of the Phacelia crenulatae group in New Mexico and in other western states as well. The above collection by Clifford is uniquely different as noted in the diagnosis, hence the description of the new species.

Arnold Clifford has traveled and collected widely in New Mexico and Arizona and is recognized as an outstanding field botanist. He was tutored by his Navajo grandmother from an early age. She was the wife of a Navajo medicine man, and as such, she was responsible for gathering plants with medicinal purposes on the Navajo Nation lands. Arnold has a keen mind and remembers every place he has ever been. He is familiar with most, if not all, of the plants on the Navajo Nation lands, and he has an eye for discerning anything that might be undescribed. We value him as a colleague and an able botanist. His botanical forays have added new taxa in the Hydrophyllaceae, Leguminosae, Onagraceae, and Compositae.

\section{MENTZELIA}

\section{Mentzelia linearifolia S.L. Welsh \& N.D. Atwood, sp. nov.}

TyPe.-USA, New Mexico, San Juan County, ca. 2 miles northeast of Ozilna Odili east of Hwy. 544, south of Juerfano Mt., $36^{\circ} 24.87^{\prime} \mathrm{N}$, $107^{\circ} 49.46^{\prime} \mathrm{W}$, at $6899 \mathrm{ft}$. elevation, in clay soil, N.D. Atwood \& Arnold Clifford 30516, 3 August 2004. Holotype: BRY!

Diagnosis.-Similis Mentzelia multiflora (Nuttall) A. Gray sed in foliis basalibus tantum brevilobatis, et foliis caulinis praecipue integris et calycibus dentibus brevioribus, et petalis paucioribus differt. 
DESCRIPTION.-Perennial, from a stout taproot; stems erect, branched from near to well above the base, $4-5 \mathrm{~cm}$ tall, scaberulous below and above, tan beneath exfoliating bark; basal rosette leaves narrowly oblanceolate, $3-6 \mathrm{~cm}$ long, shallowly pinnately lobed, the lobes and sinuses rounded, leaves above the base linear, the margins rather sparingly pinnately lobed or most of them entire; bracts and uppermost leaves linear, entire, revolute; inflorescence corymbose of 1-3 flowers; calyx lobes $6-7 \mathrm{~mm}$ long; petals 5, oblanceolate, 13-14 mm long, 5-6 $\mathrm{mm}$ wide; outer stamens petaloid, to 4 $\mathrm{mm}$ wide; capsule urceolate, $8-12 \mathrm{~mm}$ long, ca. 6-8 mm wide; seed immature.

REMARKS.-This species is a long-lived perennial of clay soils in San Juan County, New Mexico. It is included within the section Bartonia Torrey \& Gray, as interpreted by Darlington (1934). The species stands on the following combination of characteristics. It is long-lived, with evidence of previous years' rosettes along the rather elongated apex of a solitary continuation of the stem beyond its first year of growth. The basal rosette is evidently reestablished each year and soon withers as the stem elongates and bears numerous (either few or several) linear, short lateral lobes or entire throughout. Most such cauline leaves are indeed entire, or when lobed bear one or few very short lateral teeth. They hardly classify as being pinnatifid.

\section{XYLORHIZA}

\section{Xylorhiza tortifolia (Torrey \& Gray) Greene var. parashantensis N.D. Atwood \& S.L. Welsh var nov.}

Type.-Arizona, Mohave County, Grand Canyon Parashant National Monument, Cunningham Canyon, T33N, R14W, S30/SE, Yucca, Acacia, Fouquieria, Ferrocactus community, at $900 \mathrm{~m}$ elevation, on limestone ledges and talus, N.D. Atwood \& M. Madsen 26586, 29 March 2001. Holotype: BRY! Paratype: Arizona, Mohave County, Grand Canyon Parashant Na- tional Monument, $1.5 \mathrm{mi}$ due west of Cane Spring, Sandstone Canyon, with Lycium, Yucca, Agave, Rhus, and Fraxinus, at $1000 \mathrm{~m}$ elevation, N.D. Atwood \& L.C. Higgins 26927, 12 April 2001, BRY!

DiagNOSIS. - Similis $\times$ tortifolia var. tortifolia sed in involucro e bracteis attenuatis elongatis similis foliis bracteatis in caulis superioris differt.

DESCRIPTION.-Subshrubs; stems 30-40 cm tall, hirtellous and sparsely glandular; leaves 2-4.5 cm long, 1-15 mm wide, elliptic to oblanceolate, spinulose dentate-serrate, the uppermost entire, and lance-linear, hirtellous and sparsely glandular; peduncles $3-13 \mathrm{~cm}$ long; heads terminal; involucres $18-34 \mathrm{~mm}$ high and $40-70 \mathrm{~mm}$ wide; bracts slenderly long-attenuate, herbaceous essentially throughout, merely hirtellous; rays 31-34, purplish fading to tan, 25-35 mm long, 3-5 mm wide, pappus of capillary bristles, 5-6 mm long; achenes compressed, pilose.

REMARKS.-The var. parashantensis differs from the widespread var. tortifolia (Welsh et al. 2008) in its very long, long-attenuate involucral bracts and more subtly in its glandular-hirtellous pubescence. Involucres are much broader in pressed condition from the type variety. The variety is evidently local on the limestones of drainages affluent to Grand Canyon.

\section{Literature Cited}

ATwood, N.D. 1975. A revision of the Phacelia crenulatae group (Hydrophyllaceae) for North America. Great Basin Naturalist 35:127-190.

Darlington, J. 1934. A monograph of the genus Mentzelia. Annals of the Missouri Botanical Garden 21:193-226.

Welsh, S.L., N.D. ATwood, S. Goodrich, And L.C. HigGINS, EDITORS. 2008. A Utah flora. 4th edition, revised. Jones Endowment Fund, Monte L. Bean Life Science Museum, Brigham Young University, Provo, UT. 1019 pp.

Received 6 June 2011 Accepted 23 January 2013 